\title{
Effect of Lead Intoxication and D-Penicillamine Treatment on Hematological Indices in Rats
}

\author{
Efectos de Intoxicación con Plomo y Tratamiento de D-Penicilamina en Índices Hematológicos en Ratas
}

\author{
"Mohammad Jafar Golalipour; "Danial Roshandel; "Gholamreza Roshandel; \\ "Soraya Ghafari; ** Mergen Kalavi \& **Khodaberdi Kalavi
}

GOLALIPOUR, M. J.; ROSHANDEL, D., ROSHANDEL, G.; GHAFARI, S.; KALAVI, M. \& KALAVI, K. Effect of lead intoxication and D-penicillamine treatment on hematological indices in rats. Int. J. Morphol., 25(4):717-722, 2007.

SUMMARY: Lead is one of the most important environmental pollution which is toxic to many organ systems. D-penicillamine (D-P) is a chelator drug which is used for treatment of lead toxicity for several years. This study was conducted in order to evaluate the efficacy of D-P in reducing the effects of lead on hematological indices. This study was done on 36 male adult, 6-8 weeks albino Wistar rats in Gorgan University of Medical Sciences. At first male adult rats were exposed to lead acetate in their drinking water. After 8 weeks, 6 rats were selected and blood samples were prepared to assess the effects of lead toxicity. The remained lead exposed rats were divided into recovery and treatment groups where distilled water and D-P was administered for them, respectively. After lead exposure, red blood cell count increased slightly, but hemoglobin and hematocrite were decreased. Also MCV and $\mathrm{MCH}$ were significantly decreased $(\mathrm{P}<0.05)$. RDW, PDW and MPV were significantly higher in lead exposed rats $(\mathrm{P}<0.05)$. After recovery period, most of parameters were close to normal while there were no significant differences between recovery and treatment groups. This study showed that hematologic effects of lead are reversible and D-P administration do not play an important role in subchronic lead intoxication.

KEY WORDS: Lead toxicity; D-Penicillamine; Recovery; Blood indices; Rat.

\section{INTRODUCTION}

Lead is a dangerous heavy metal which is widely spread in the environment. Lead content in the air, food and tap water has increased several folds during recent years due to extensive use of this metal in petrol, paints, battery and other industries (Tuormaa, 1995). Despite of attempts for reducing the exposure to this metal, there are still some reports of cases with severe lead toxicity (Hershko, 2005; Roche et al., 2005 and Coyle et al., 2005). On the other hand, chronic lead poisoning is a problem which threats mankind's life and seems to be an unknown reason for some diseases during aging (Coyle et al. and Vig \& HU, 2000).

The toxic effects of lead on blood indices are well known. Significant decrease in RBC count, hematocrit (Hct) and hemoglobin $(\mathrm{Hb})$ were seen in rats and human with high blood lead levels. (Alexa et al., 2002; Othman et al., 2004; Toplan et al., 2004; Hofmann \& Segewitz, 1975; Noori et al., 2003 and Klauder \& Petering, 1977).
D-Penicillamine (D-P) is a chelator drug which is used for treatment of lead toxicity for several years (Lyle, 1981). The efficacy of D-P in reducing blood lead level (BLL) has made it a good choice for treatment of chronic lead poisoning in adults (González-Ramírez et al., 1990). D-P administration can increase the urinary excretion of lead because of complexes which it forms with this heavy metal (González-Ramírez et al.). In many cases BLL fell down to acceptable range after D-P treatment (Shannon et al., 1988). However, long period of administration and side effects of D-P have complicated its use in the treatment of lead poisoning (Shannon et al.).

The present study was conducted to evaluate the effects of subchronic oral lead intoxication on blood indices of adult rats and efficacy of D-penicillamine in reducing these effects.

\footnotetext{
* Department of Anatomical Sciences, Gorgan University of Medical Sciences, Iran.

*** Department of Hematology and Immunology, Gorgan University of Medical Sciences, Iran.
} 


\section{MATERIAL AND METHOD}

Animals. 36 male adult, 6-8 weeks albino Wistar rats were purchased from pasture institute (Tehran, Iran) and transferred to animal laboratory at Gorgan University of Medical Sciences (GOUMS). They were kept under constant temperature (22士 $1{ }^{\circ} \mathrm{C}$ ), humidity (50\%) and 12/12 cycle of light and darkness with ad libitum access to food and drinking water.

Experimental protocols. This study consists of two protocols. The first protocol was conducted to assess the effects of lead intoxication on hematological parameters of rats. In the second one, reversibility of these effects and the efficacy of D-P administration were evaluated and compared.

Protocol I: After one week of adaptation, animals were divided randomly into three groups as follow: 12 negative control, 6 positive control and 18 test rats and distilled water, acetic acid $(0.13 \% \mathrm{~V} / \mathrm{V})$ and lead acetate dissolved in distilled water $(0.4 \% \mathrm{~W} / \mathrm{V})$ was administered for them respectively as daily water supply for eight weeks. A subsequent amount of 5 $\mathrm{N}$ HCL was added to lead acetate solution to preclude the precipitation of lead salts (Ronis et al., 2001). The $\mathrm{pH}$ of the solutions was 5.5-6 and they were made fresh daily. At the end of 8th week, treatments were discontinued and rats drink tap water for one day. Then six rats were selected from each group (all positive control rats), and sacrificed after anesthesia.

Protocol II: The remained six negative control and 12 test rats enrolled in the second study. Test rats were divided into two groups of six animals. Distilled water was administered for six $\mathrm{Pb}$ exposed rats for seven weeks (recovery group), as well as control group. The other group of six test rats was given distilled water for one week followed by a six week period of $25-35 \mathrm{mg} / \mathrm{kg}$-b-wt/day of oral Dpenicillamine treatment. D-P was purchased as $250 \mathrm{mg}$ capsules (RUBIÓ, Spain). The content of each capsule was powdered completely and given to rats through their mouth every day at one dose and one time ( 1:00 pm) with empty stomach $(2 \mathrm{~h}$ before and $1 \mathrm{~h}$ after administration). Then D-P treatment was discontinued and all rats drink tap water for one day and sacrificed after anesthesia.
Samples and blood analysis. Blood samples were collected from their hearts and transferred to lead free polyethylene tubes containing EDTA. A cell counter was applied for complete blood count (CBC) test and blood indices including red blood cell count (RBC), hemoglobin $(\mathrm{Hb})$, hematocrit (Hct), MCV (mean corpuscular volume), $\mathrm{MCH}$ (mean corpuscular hemoglobin), RDW (red blood cell distribution width), PDW (platelet distribution width), and MPV (mean platelet volume) were measured.

Statistical analysis. The data were analyzed using student's t-test and differences between group means were determined by the One-Way ANOVA followed by Tuckey HSD test. Among P-values those less than 0.05 were assumed significant.

\section{RESULTS}

After eight weeks of lead intoxication, small increase in RBC count was seen in test group, which was not significant compared with negative and positive control groups. $\mathrm{Hb}$ and Hct levels were decreased by $5.2 \%$ and $9 \%$, respectively compared with negative control group. Also significant reduction in MCV (10.5\%) and MCH (11.2\%) levels was observed in lead treated rats $(\mathrm{P}<0.05)$. There was no significant difference between negative and positive control groups in none of variables (Table I).

After recovery or D-P treatment, RBC count was higher in both groups compared with control group but this difference was not significant. Hb was $2.8 \%$ lower in both groups and Hct was slightly higher in D-P treated and recovered rats (3\% and $2.6 \%$, respectively). $\mathrm{MCV}$ was lower in both groups compared with control group as well as $\mathrm{MCH}$. PDW and MPV were equal in control and D-P treated rats, but recovered rats had lower PDW and MPV levels. RDW was significantly higher in both test groups compared with control group $(\mathrm{P}<0.05)$ (Table II).

When only $\mathrm{Pb}$ exposed rats were compared with rats in recovery or D-P treatment groups, RBC count and Hct

Table I. Mean \pm SD of blood indices of negative control, positive control and lead exposed rats at the end of the protocol I.

\begin{tabular}{lcccccccc}
\hline Group & $\begin{array}{c}\mathbf{R B C} \\
(\mathbf{1 0} / \mathbf{m l})\end{array}$ & $\begin{array}{c}\text { Hb } \\
(\mathbf{g} / \mathbf{d l})\end{array}$ & $\begin{array}{c}\text { Het } \\
(\boldsymbol{\%})\end{array}$ & $\begin{array}{c}\text { MCV } \\
(\mathbf{f l})\end{array}$ & $\begin{array}{c}\text { MCH } \\
(\mathbf{p g})\end{array}$ & $\begin{array}{c}\text { RDW } \\
(\mathbf{\%})\end{array}$ & $\begin{array}{c}\text { PDW } \\
(\mathbf{\%})\end{array}$ & $\begin{array}{c}\text { MPV } \\
(\mathbf{f l})\end{array}$ \\
\hline Negative control & $8.4 \pm 0.4$ & $13.4 \pm 0.6$ & $45.1 \pm 3.0$ & $52.3 \pm 2.3$ & $16.2 \pm 0.5$ & $14.4 \pm 0.4$ & $30.9 \pm 1.7$ & $7.1 \pm 0.6$ \\
Positive control & $8.7 \pm 0.5$ & $14.0 \pm 0.6$ & $45.0 \pm 3.2$ & $50.3 \pm 2.2$ & $16.1 \pm 1.0$ & $14.6 \pm 0.4$ & $33.3 \pm 0.8$ & $7.4 \pm 0.2$ \\
Lead intoxication & $8.8 \pm 0.6$ & $12.7 \pm 0.5$ & $41.0 \pm 1.5$ & $46.8 \pm 2.8 * \dagger$ & $14.4 \pm 0.8 * \dagger$ & $17.2 \pm 0.8 * \dagger$ & $35.3 \pm 0.4 * \dagger$ & $8.3 \pm 0.1 * \dagger$ \\
\hline
\end{tabular}

- Units in parentheses: $10^{6} / \mathrm{ml}=$ million per milliliter, $\mathrm{g} / \mathrm{dl}=$ gram per deciliter, $\mathrm{fl}=$ femtoliter, $\mathrm{pg}=$ picogram .

* Significant compared with negative control. $\dagger$ Significant compared with positive control. 
level were higher in both of recovered and D-P treated animals. Also $\mathrm{Hb}$ and $\mathrm{MCV}$ were higher and there was a significant decrease in PDW and MPV levels $(\mathrm{P}<0.05)$. Data are shown in Table III.

Table II. Mean \pm SD of blood indices of control, recovered and D-P treated rats at the end of the protocol II.

\begin{tabular}{lcccccccc}
\hline Group & $\mathbf{R B C}$ & $\begin{array}{c}\mathbf{H b} \\
(\mathbf{1 0} / \mathbf{m l})\end{array}$ & $\begin{array}{c}\text { Het } \\
(\mathbf{\%})\end{array}$ & $\begin{array}{c}\mathbf{M C V} \\
(\mathbf{f l})\end{array}$ & $\begin{array}{c}\text { MCH } \\
(\mathbf{p g})\end{array}$ & $\begin{array}{c}\text { RDW } \\
(\boldsymbol{\%})\end{array}$ & $\begin{array}{c}\text { PDW } \\
(\boldsymbol{\%})\end{array}$ & $\begin{array}{c}\text { MPV } \\
(\mathbf{f l})\end{array}$ \\
\hline Control & $8.7 \pm 0.7$ & $14.2 \pm 1.9$ & $45.0 \pm 3.2$ & $50.9 \pm 1.8$ & $16.0 \pm 1.6$ & $14.6 \pm 0.6$ & $32.6 \pm 1.0$ & $7.4 \pm 0.3$ \\
Recovery & $9.4 \pm 0.7$ & $13.8 \pm 0.9$ & $46.2 \pm 4.1$ & $48.8 \pm 1.0$ & $14.6 \pm 0.2$ & $16.5 \pm 0.4 *$ & $31.7 \pm 1.0$ & $7.2 \pm 0.3$ \\
D-P treatment & $9.6 \pm 0.4$ & $13.8 \pm 0.4$ & $46.4 \pm 1.9$ & $48.0 \pm 1.3$ & $14.3 \pm 0.4 *$ & $17.4 \pm 0.5 *$ & $32.5 \pm 0.4$ & $7.4 \pm 0.2$ \\
\hline
\end{tabular}

- Units in parentheses: $10^{6} / \mathrm{ml}=$ million per milliliter, $\mathrm{g} / \mathrm{dl}=$ gram per deciliter, $\mathrm{fl}=$ femtoliter, $\mathrm{pg}=$ picogram .

* Significant compared with control group.

Table III. Mean $\pm \mathrm{SD}$ of blood indices of only $\mathrm{Pb}$ exposed, recovered and $\mathrm{D}-\mathrm{P}$ treated rats.

\begin{tabular}{lcccccccc} 
Group & $\mathbf{R B C}$ & $\mathbf{H b}$ & $\begin{array}{c}\text { Het } \\
(\mathbf{\%})\end{array}$ & $\begin{array}{c}\text { MCV } \\
(\mathbf{f l})\end{array}$ & $\begin{array}{c}\text { MCH } \\
(\mathbf{p g})\end{array}$ & $\begin{array}{c}\text { RDW } \\
(\boldsymbol{\%})\end{array}$ & $\begin{array}{c}\text { PDW } \\
(\boldsymbol{\%})\end{array}$ & $\begin{array}{c}\text { MPV } \\
(\mathbf{f l})\end{array}$ \\
Lead intoxication & $8.8 \pm 0.6$ & $12.7 \pm 0.5$ & $41.0 \pm 1.5$ & $46.8 \pm 2.8$ & $14.4 \pm 0.8$ & $17.2 \pm 0.8$ & $35.3 \pm 0.4$ & $8.3 \pm 0.1$ \\
Recovery & $9.4 \pm 0.7$ & $13.8 \pm 0.9$ & $46.2 \pm 4.1^{*}$ & $48.8 \pm 1.0$ & $14.6 \pm 0.2$ & $16.5 \pm 0.4$ & $31.7 \pm 1.0^{*}$ & $7.2 \pm 0.3 *$ \\
D-P treatment & $9.6 \pm 0.4$ & $13.8 \pm 0.4$ & $46.4 \pm 1.9^{*}$ & $48.0 \pm 1.3$ & $14.3 \pm 0.4$ & $17.4 \pm 0.5$ & $32.5 \pm 0.4 *$ & $7.4 \pm 0.2 *$ \\
\hline
\end{tabular}

- Units in parentheses: $10^{6} / \mathrm{ml}=$ million per milliliter, $\mathrm{g} / \mathrm{dl}=$ gram per deciliter, $\mathrm{fl}=$ femtoliter, $\mathrm{pg}=$ picogram .

* Significant compared with only lead intoxication.

\section{DISCUSSION}

In this study, subchronic lead intoxication caused a slight increase in the number of RBCs while $\mathrm{Hb}$ and Hct were increased. Also $\mathrm{MCV}$ and $\mathrm{MCH}$ were decreased significantly in lead exposed animals. Increased level of RBC count which was observed in lead exposed rats in our study was reported previously by other researchers (Iavicoli et al., 2003; Jacob et al, 2000). Iavicoli et al. observed that small increase of blood $\mathrm{Pb}$ was associated with increased $\mathrm{RBC}$ count and also increased $\mathrm{Hb}$ and Hct levels, but in our study, $\mathrm{Hb}$ and Hct were reduced despite of high $\mathrm{RBC}$ count in lead treated rats. It may be due to low hemoglobin production because of lead induced disturbance of heme biosynthesis (Wildman et al.,1976).

In our study, may be bone marrow could overcome lead toxicity because of subchronic exposure which was not at high dose, but it suppressed the production of Hb. Low $\mathrm{Hb}$ level might result in reduced oxygen transfer by $\mathrm{RBCs}$, which was compensated by increased number of these cells. Also, tissue hypoxia is a possible mechanism for high production of RBCs in moderate lead poisoning. MCV and $\mathrm{MCH}$ levels were decreased after lead intoxication in our study that it was in agreement with several studies (Noori et al.; Falke \& Zwennis, 1990; Antonowicz et al., 1991).

In this study, lead intoxication had the same effects on blood indices that were observed previously in other researches (Alexa et al.; Othman et al.; Toplan et al.; Hofmann \& Segewitz; Noori et al.; Iavicoli et al.; Jacob et al.; Wildman et al; Falke \& Zwennis and Antonowicz et al.).

Falke \& Zwennis showed that effects of lead on hematological parameters are reversible after a period of recovery in rabbits. It is believed that lead disturbs intestinal absorption of some essential trace elements involved in RBC activities (Antonowicz et al. and Morawiec, 1991). So, discontinuation of lead exposure may result in improvement of affected parameters by improved absorption of these trace elements.

Peter \& Strung (1983) reported that blood $\mathrm{Pb}$ fell down immediately after discontinuation of lead exposure in animals. In other study on patients with lead poisoning, there was no significant reduction in blood $\mathrm{Pb}$ after a recovery period of about four months (González-Ramírez et al.).

In our study, although there were differences between normal ranges and ranges that were seen in rats of recovery group, but it seems that they were going to be improved after recovery period. It was previously seen that administration of D-P should be continued for more than two months to cause significant reduction in blood $\mathrm{Pb}$ (González-Ramírez et al. and Shannon \& Townsend). Another study on petrol sniffers showed that urinary excretion 
of $\mathrm{Pb}$ did not increase appreciably after administration of $\mathrm{D}-\mathrm{P}$ (Burns \& Currie, 1995). In our studyno obvious differences were observed between recovery and treatment groups after D-P treatment.

There are evidences about side effects of D-P, including adverse reactions, abdominal pain, depression of platelet count, leukopenia and etc. (Shannon et al. and Shannon \& Townsend, 2000). We did not observe signs of D-P induced impairments in measured blood parameters in D-P treated animals.

In fact, in the present dose and duration of treatment (25-35 mg/kg/day for six weeks), D-P had no significant effects on hematological parameters that were measured in our study.

Our study also revealed that RDW, PDW and MPV were increased significantly in lead treated rats.

Peng et al. (2002) have reported that RDW increased significantly in lead expose workers (Peng et al.). High RDW levels may reflect a disruption in erythropoiesis that it may occur during some hematological disorders, such as anemia and iron deficiency (Laso et al., 1990 and Docci et al., 1989).

According to our hypothesis, iron deficiency (may be due to intestinal malabsorption) caused disruption of heme biosynthesis and low oxygen transfer might have resulted in compensatory increase in the rate of RBC production, which can be a possible reason for high RDW levels.

After recovery or treatment, RDW was still significantly higher than normal. It might be due to high level of RBC production after the discontinuation of lead exposure. The two indicators of platelet size and activity, PDW and RDW, were increased significantly after lead exposure. However, we observed that these changes in PDW and MPV were reversible and they were close to normal after both of treatment and recovery periods.

The exact mechanism of the action of lead on platelets is unknown. However, Noori have found that platelet count increased significantly after 12 weeks of oral lead exposure. Also in previous studies, some cases of thrombocytopenia after lead intoxication followed by thrombocytosis have been reported (Sudakova et al., 1983).

There is evidence about increase of PDW in sickle cell anemia (Amin et al., 2004) that may contribute role of erythrocyte abnormalities in platelet dysfunction.

Also it was previously shown that weight loss may be associated with increase in MPV levels (Toplak \& Wascher, 1994) that in our study reduced weight gain may be a similar condition.

Several studies have shown that high MPV is a potential predictor of vascular disorders like as atherosclerosis, coronary artery disease and ischemic stroke (Toplak \& Wascher and Yilmaz et al., 2004).

Although impairment of intestinal absorption of trace elements, weight loss and erythrocyte abnormalities are possible mechanisms of platelet dysfunction, the exact mechanism should be studied more.

These findings open a new window toward the understanding of the cardiovascular and cerebrovascular risks of lead exposure due to platelet dysfunction. Of course more studies are needed to explain that how lead poisoning interacts with coagulation and what are the potential risks.

In conclusion the present study showed that lead induced hematological changes were reversible after a period of recovery and D-penicillamine treatment did not effect in the improvement of impaired parameters affected by lead intoxication.

\section{ACKNOWLEDGMENTS}

The authors wish to thank Dr. MS Asghari and Mr Bazoori for their full scientific and sincere cooperation.

GOLALIPOUR, M. J.; ROSHANDEL,D., ROSHANDEL, G.; GHAFARI, S.; KALAVI, M. \& KALAVI, K. Efectos de intoxicación con plomo y tratamiento D-penicillamina en índices hematológicos en ratas. Int. J. Morphol., 25(4):717-722, 2007.

RESUMEN: El plomo es uno de los más importantes contaminantes ambientales, tóxico para la mayoría de los sistemas orgánicos. La D-penicillamina (D-P) es una droga quelante, la cual se ha usado para el tratamiento de la toxicidad por plomo durante varios años. Este estudio fue dirigido para evaluar la eficacia de la D-P en la reducción de los efectos del plomo en los índices hematológicos. Este estudio se realizó en 36 machos adultos de ratas Wistar albinas de 6-8 semanas, en la Universidad de Ciencias Médicas de Gorgan, Irán. Al inicio, las ratas machos adultas fueron expuestas al acetato de plomo en el agua de beber. Después de 8 semanas, 6 ratas se seleccionaron para evaluar los efectos de la toxicidad del plomo en muestras sanguíneas. Las restantes ratas expuestas fueron divididas para su recuperación, a las cuales se les administró agua destilada y un grupo con tratamiento al que se le suministró D-P. Después de la exposición al plomo, el conteo de glóbulos rojos se incrementó ligeramente, pero la hemoglobina y el hematocrito disminuyeron. También el MCV y el valor de MCH disminuyeron significativamente $(\mathrm{P}<0,05)$. Los valores de RDW, PDW y MPV fueron significativamente altos en las ratas expuestas al plomo ( $<<0,05)$. Luego del periodo de recuperación, la mayoría de los parámetros se acercaron al valor normal y no hubo diferencias significativas entre el grupo recuperado y con tratamiento. Este estudio mostró que los efectos hematológicos del plomo son reversibles y la administración de D-P no juega un rol importante en la intoxicación subcrónica.

PALABRAS CLAVE: Toxicidad del plomo; D-Penicillamina; Recuperación; Índices sanguíneos; Ratas. 


\section{REFERENCES}

Alexa, I. D; Mihalache, I. L; Panaghiu, L. \& Palade, F. Chronic lead poisoning- a" forgotten"cause of anemia. Rev. Med. Chir. Soc. Med. Nat. Iasi., 106(4):825-8, 2002.

Amin, M. A.; Amin, A. P. \& Kulkarni, H. R. Platelet distribution width (PDW) is increased in vaso-occlusive crisis in sickle cell disease. Ann. Hematol., 83(6):331-5, 2004.

Antonowicz, J.; Andrzejczak, R.; Kuliczkowski, K. \& Smolik, R. Levels of trace elements in the serum and erythrocytes and some parameters of erythrocyte heme metabolism (FEP, ALA-D, ALA-U) in copper foundry workers. Pol. J. Occup. Med. Environ. Health., 4(4):339-47, 1991.

Burns, C. B. \& Currie, B. The efficacy of chelation therapy and factors influencing mortality in lead intoxicated petrol sniffers. Aust. N. Z. J. Med., 25(3):197-203, 1995.

Coyle, P.; Kosnett, M. J. \& Hipkins, K. Severe lead poisoning in the plastic industry: a report of three cases. Am. J. Ind. Med., 47(2):172-5, 2005.

Docci, D.; Delvecchio, C.; Gollini, C.; Turci, F.; Baldrati, L. \& Gilli, P. Red blood cell volume distribution width (RDW) in uraemic patients on chronic haemodialysis. Int. J. Artif. Organs., 12(3):170-4, 1989.

Falke, H. E. \& Zwennis, W. C. Toxicity of lead acetate to female rabbits after chronic subcutaneous administration. 1. Biochemical and clinical effects. Arch. Toxicol., 64(7):522-9, 1990.

González-Ramírez, D.; Zuñiga-Charles, M. \& NarroJuárez, A. Mobilization of lead in patients with chronic poisoning by that metal.Oral penicillamine. Arch. Invest. Med. (Mex)., 21(3):279-83, 1990.

Hershko C. Lead poisoning by contaminated flour: an unfinished story. Harefuah., 144(7):458-528, 2005.

Hofmann, U. \& Segewitz, G. Influence of chelation therapy on acute lead intoxication in rats. Arch. Toxicol., 34(3):213-25, 1975.

Iavicoli, I.; Carelli, G.; Stanek, E. J; Castellino, N. \& Calabrese, E. J. Effects of low doses of dietary lead on red blood cell production in male and female mice. Toxicol. Lett., 137(3):193-9, 2003.
Jacob, B.; Ritz, B.; Heinrich, J.; Hoelscher, B. \& Wichmann, H. E. The effects of low-level blood lead on hematologic parameters in children. Environ. Res., 82(2):150-9, 2000.

Klauder, D. S. \& Petering, H. G. Anemia of lead intoxication: A role of Copper. J. Nutr., 107(10):1779$85,1977$.

Laso, F. J.; Mateos, F; Ramos, R; Herrero, F; PérezArellano, J.L. \& González-Buitrago, J.M. Amplitude of the distribution of erythrocyte size in the differential diagnosis of microcytic anemia. Med. Clin. (Barc)., 94(1):1-4, 1990.

Lyle, W. H. Penicillamine in metal poisoning. J. Rheumatol. Suppl., 7:96-9, 1981.

Morawiec, M. Effects of harmful trace elements on iron zinc and copper: their interactions in animals and humans. II. Lead. Rocz. Panstw. Zakl. Hig., 42(2):1216,1991 .

Noori, M. M.; Heidari, Z; Mahmoudzadeh Sagheb, H. \& Barbarestani, M. Effects of chronic lead acetate intoxication on blood indices of male adult rat. Daru. Pharm. J., 11(4): 147-51, 2003.

Othman, A. I.; Al Sharawy, S. \& El-Missiry, M. A. Role of melatonin in ameliorating lead induced haematotoxicity. Pharmacol. Res., 50(3):301-7, 2004.

Peng, S.; Zhang, C; Wang, C; Wei, M.; Zhang, J.; Xi, Z. \& Yang, X. The investigation on the changes of haematological parameters in the occupationally lead exposed workers. Zhonghua Lao Dong Wei Sheng Zhi Ye Bing Za Zhi., 20(5):334-5, 2002.

Peter, F. \& Strung, G. Effects of ingested lead on concentration of blood and tissue lead in rabbits. Clin. Biochem., 16(3):202-5, 1983.

Roche, A.; Florkowski, C. \& Walmsley, T. Lead poisoning due to ingestion of Indian herbal remedies. $N$. Z. Med. J., 118(1219):U1587, 2005.

Ronis, M. J.; Aronson, J.; Gao, G. G; Hogue, W.; Skinner, R. A.; Badger, T. M. \& Lumpkin, C. K. Jr. Skeletal Effects of Developmental Lead Exposure in Rats. Toxicol. Sci., 62(2):321-9, 2001. 
Shannon, M.; Graef, J. \& Lovejoy, F. H Jr. Efficacy and toxicity of D-penicillamine in low-level lead poisoning. J. Pediatr, 112(5):799-804, 1988.

Shannon, M.W. \& Townsend, M.K. Adverse effects of reduced-dose D-Penicillamine in children with mild-tomoderate lead poisoning. Ann. Pharmacother, 34(1):158, 2000 .

Sudakova, A. I.; Shevchenko, Zh.T. \& Nosova, L. I. Peripheral blood and bone marrow cell status of white rats with long-term lead exposure. Tsitol. Genet., 17:37, 1983.

Toplak, H. \& Wascher, T.C. Influence of weight reduction on platelet volume: different effects of a hypocaloric diet and a very low calorie diet. Eur. J. Clin. Invest., 24(11):778-80, 1994.

Toplan, S.; Ozcelik, D.; Gulyasar, T. \& Akyolcu, M. C. Changes in hemorheological parameters due to lead exposure in female rats. J. Trace. Elem. Med. Biol., 18(2):179-82, 2004.

Tuormaa, T. E. The adverse effects of lead. J. Orthomol. Med., 10(3-4):149-64, 1995.

Vig, E. K. \& HU, H. Lead toxicity in older adults. J. Am. Geriatr. Soc., 48(11):1501-6, 2000.

Wildman, J. M.; Freedman, M. L; Rosman, J. \& Goldstein, B. Benzene and lead inhibition of rabbit reticulocyte heme and protein synthesis: evidence for additive toxicity of these two components of commercial gasoline. Res. Commun. Chem. Pathol. Pharmacol., 13(3):473-88, 1976.

Yilmaz, M. B.; Saricam, E.; Biyikoglu, S. F.; Guray, Y.; Guray, U.; Sasmaz, H. \& Korkmaz, S. Mean platelet volume and exercise stress test. J. Thromb. Thrombolysis., 17(2):115-20, 2004.
Correspondence to:

Dr. Mohammad Jafar Golalipour (Ph. D) Department of Anatomical Sciences, Gorgan University of Medical Sciences Gorgan - IRAN

P. O. Box: $49175-553$

Tel \& Fax: +98-171-4421289

Email: mjgolalipour@yahoo.com

Received: 16-07-2007

Accepted: 24-08-2007 